8. Jel'nikova, G. V. (Ed.) (2010). Kvalifikacijni vymogy do profesijnoi' dijal'nosti pedagogichnyh pracivnykiv. Analitychnyj zvit za rezul'tatamy doslidzhennja z osvitn'oi' polityky. Kn. 2. Kyiv-Cherkasy, 96.

9. Kogut, I., Stadnyj, Je. (2015). Bjudzhet osvity ta nauky 2016: shho pryjnjaly deputaty. CEDOS. Available at: http://www.cedos.org.ua/uk/osvita/biudzhet-osvity-ta-nauky2016-shcho-pryinialy-deputaty

10. Demchuk, O. (2005). Blagodijni fondy - zaporuka prozorogo vykorystannja neurjadovyh koshtiv u derzhavnyh zakladah osvity. Gromadjans'ka Osvita, 6. Available at: http:// osvita.khpg.org/index.php?id=1123088405

Рекомендовано до публікачії д-р пед. наук, професор Островерхова Н. М. Дата надходження рукопису 06.09.2016

Климчук Ірина Олександрівна, кандидат педагогічних наук, старший науковий співробітник, Інститут педагогіки, Національна Академія педагогічних наук України, вул. Січових Стрільців, 52-А, м. Київ, Україна, 04053

E-mail: Klimchuk.irina@gmail.com

УДК 374.32

\title{
RESEARCH GENDER SOCIALIZATION AS SOCIO-PEDAGOGICAL PROBLEM
}

\section{(C) V. Syniakova}

\begin{abstract}
Метою статті є дослідження поняття «гендерна сочіалізація», як соиіально педагогічної проблеми. Відповідно до мети проаналізовано поняття «сочіалізація» та визначено ї̈ феномени. Провідним агентом сочіалізації визнано родину, а важливою складовою соціалізації- «гендерну соиіалізацію». У статті висвітлено сутнісні характеристики понять «стать» та «тендер», подане авторське визначення поняття «тендер» та розмежовано поняття «гендерна» та «статеворольва» соиіалізаџія
\end{abstract}

Ключові слова: гендерна сочіалізація, стать, гендер, механізми соціалізаџї, гендерна освіта, гендерне виховання

The purpose of the article is to present a study of the concept of "gender socialization" as a socio-pedagogical problem. According to the purpose of the article, we analyzed the notion of "socialization" and its phenomena. The leading agent of socialization is recognized as a family and an important part of socialization is "gender socialization." The article represents the main characteristics of the concepts of "sex" and "gender", the author's definition of the concept of "gender" and the difference between the concept of "gender" and "role-gender socialization". It was also studied the relationships between the concepts of "gender socialization", "gender training» and "gender education». Summing up the position expressed by, we proposed a formula to describe the process of gender socialization

Keywords: socialization, gender socialization, agents of socialization, mechanisms of socialization, gender, gender education

\section{Introduction}

In the course of one of its stages, the historical development of humanity naturally led to the emergence of a community of people which must act as a single entity. Thus, the complicated problem of overcoming the multivalency of the approaches to the subjective perception of the world arose and it was inevitable to develop a coherent view about it, i. e. the construction of a common vision for all. In the animal environment (kingdom), the problem of coordinating actions between private individuals is solved not only at the genetic level, but also at the level of the formation of a purely individual experience of interaction with other individuals.

People solve the problem of subjective separateness when they create common for all «environment concepts» using artificial external samples, such as signs (language, customs, traditions, etc.). By learning the system of generally accepted notions, ideas, and views, through a general activity and communication with other people, the «socialized subject» is included in the social environment of people of a certain culture, relatively acquires the human essence. In this connection, the problems of socialization never lose their relevance, they only change their perspective.

\section{Literature review}

The comprehension of the human socialization problem began long before the propagation of the relevant term. The question of how a person becomes a competent member of society has always been at the focus of philosophers, writers and authors of memoirs and in the last third of the XIX century it began to be intensively explored by sociologists and social psychologists. Currently, the concept of "socialization" is a central one in the different social sciences: philosophy, psychology, pedagogy, sociology, political science and others.

Since the term "socialization" is widely used by researchers of the various scientific branches, we believe 
it is appropriate, based on the purpose of our study, to differentiate the concept of "socialization" of other synonyms, to outline its definition in the socio-pedagogical science and to consider in detail its important direction "gender socialization." After all, positive gender socialization of personality promotes its adequate social development, self-improvement and self realization that ultimately affects the process of revival of the society.

Given the fact that the issue of socialization is not new in the socio-pedagogical science, we do not analyze in detail all its categories and phenomena. At the same time, we emphasize that a number of aspects of the socialization of the growing-up personality is actually the same in modern conditions. They are associated with transitions happening in the family, the school (as the institution of socialization), as well as in the State as a whole. In our article, the question of gender socialization is raised.

They will underline the methodological basis of our research.

We found a variety of science approaches to the study of the process of socialization based on different views. Thus, the analysis of sociological, psychological, socio-pedagogical and other sources shows that the definite term remains a polysemantic and multidimensional one, close, in some cases, to education, and in others - to the formation of a personality.

Social pedagogy specifies the notion of "socialization", revealing it as the "process of transfer of the generalized experience of culture (roles, values, abilities, knowledge, norms) to individual members» [1].

In our research we consider socialization as a complex of socio-educational phenomena which is the process of interiorization of socio-cultural norms by the individual that are inherent in a specific society according to historical time. This takes place through agents of socialization via mechanisms (in their individual ratio), under the influence of social factors underlying the behaviour of the individual and its entry into the social status.

The study of the factors and mechanisms of socialization adds a special value to its socio-pedagogical understanding. In the relevant literature [2], the mechanisms of socialization are defined as a set of tools and methods that ensure the process of inheritance and transformation of social and cultural experiences of a particular society.

In our opinion, the approach to the mechanisms of socialization, presented by D. Meade, is of utter importance in the context of gender socialization. The researcher proves that the person, in continuous interaction with society, reproduces the model (roles) of interpersonal relations which are most often repeated in his/her life [1]. Considering this peculiarity, the main mechanism and structure of personality is her role essence, including role-gender socialization [3].

Thus, identification and typification are among the most important mechanisms of gender socialization and identity. Among the first of these mechanisms, is the identification by the child of his/her behavior with that of the adult representatives of their gender, especially parents, and the second mechanism involves the active participation of the adults in the process of assimilating the samples submitted by the child. The variety of conditions, i.e. the factors of socialization, does not lead to the denial of the notion that they are an important part of the socialization of the personality. In particular, we rely on the division, represented by A. Mudrik, that the megafactors space, planet, world, Internet; the macrofactors country, ethnic group, society, State; the mezofactors - region, type of settlement, subculture and the microfactors - family, neighbors and microsociety, peer groups) [4]. It should be emphasized that each of these factors may, in addition to space and the planet, somehow affect the role-gender self-determination of the growing-up personality, broadcast and instill socio-cultural norms and patterns of behavior that are inherent in a particular country, nation, region, subculture, etc. Such influence, especially of the microfactors, on the general and role-gender formation of the individual is carried out through agents of socialization such as: the family, preschool, school, informal institutions and mass media. In order to complete the analysis of the phenomena of socialization, it is important to note that from the perspective of gender mainstreaming, the leading factor and agent of socialization is the family. It is the family that is the primary source of socialization and the family, first and foremost, gives the chance to the individual to be created as a social-personality. As we already mentioned above, the content of socialization is the social experience, including the experience of interaction between individuals of different sex, social role models, including parents and other persons who demonstrate examples of behaviour of the representatives of a certain sex, means of implementation and conferment which are transformed in the process of the development of a society [5].

Therefore, the gender socialization is an important component of the overall process of socialization. If socialization is considered, on the one hand, as the process of integration and adaptation of man in society, and on the other hand, as the process of selfdevelopment and self-realization, in studying the problems of gender socialization, we need to consider both of these aspects in their relationship.

\section{Purpose and objectives of research}

The aim of our research is the study of key positions of the "gender socialization."

In referrence to the problem of "gender socialization", we consider it appropriate to carry out its disclosure in the following areas of study:

1) the essence and specificity of the notions of "sex" and "gender", the theory of gender and its components;

2) the essence of gender socialization and its correlation with the related concepts: differential, sex-role and role-gender socializations;

3) the relationship of the "gender socialization », «gender training» and « genderne education » categories. 


\section{Reserch gender socialization as socio-peda- gogical problem}

We found that the concept of "gender", as a sociocultural thinking construct, is the study object of many of the Humanities. In particular, in postmodern philosophy the concept of gender was assigned to independent scientific branches in the context of the Humanities in the 1960-ies of the XX century, i.e. Philosophy, Cultural studies, Ethnology, Sociology, Social psychology, Linguistics, etc. Researches carried out by women gradually degenerated into gender investigations where in the approaches according to which all aspects of human society, culture and relationships are gender ones of primary importance. In the 1980s and 1990s of the 20th century gender studies have become fairly common, although the understanding and use of the term "gender" still remains ambiguous [6].

Psychologists such as J. Butler, C. Böhm, S. Bern, F. Gejs, K. Leaper, T. Murachver and K. Robertson, $\mathrm{K}$. Horney, etc., play the leading role in the field of gender studies.

In the works of scientists from the former Soviet Union this problem is treated mainly in two areas, i.e.: the psychological and the social-psychological. This emphasizes that both sexes are psychologically balanced although different in content.

Today, the various aspects of gender mainstreaming represent important areas of research in the modern domestic science. Therefore, our research is directed to analysing the nature and specifics of the notions of "sex" and "gender".

Therefore, pursuant to the synthesis conducted by T. Lauretis (1987), we found that in the "American Dictionary of the English language" "gender" is defined as the classification of sex; in roman, in the spanish and french explanatory dictionaries this category generally is not associated with a category "sex"; whereas in the translation from English, the term literally means grammatical gender - feminine, masculine and neutral [7].

It should be noted that studies of Ukrainian research publications such as the "New explanatory dictionary of the Ukrainian language", compiled by V. Yaremenko, O. Slipushko, and the "Psychological dictionary of modern terms", state that the investigated concept is not generally considered and is not analyzed. This situation has generated a need for substance analysis of the definite term with the aim of identifying its author's understanding.

The results of the indicated analysis allow us to state that the understanding of the category "gender" is traditionally considered within the theories of social construction, the cultural metaphor, the role-gender socialization and the social stratification.

In addition, we consider it necessary to highlight the system theory. In this case, it is established that the interpretation of this concept varies from its identification with the system mastering the social relations to the inclusion of this phenomenon in a number of components allowing you to present it as a multi-dimensional structure that contains the following: gender, sexuality, gender (role-gender) identity and gender role. We can combine the listed components in two groups of characteristics: actually sexual, rooted in biology, and role-gender, with an emphasis on the socio-cultural peculiarities.

However, it should be emphasized that the phenomena of "sex" and "gender" are closely related, but they are not identical. The main characteristics that reflect the above-mentioned difference between the notions of "sex" and "gender", are presented in Fig. 1.

In summing up the above provisions, we believe that it is appropriate to continue following the theory of social construction that allows us to examine the phenomenon of gender as a complex socio-cultural process constructed by society based on the differences in men's and women's roles, behavior, mental and emotional characteristics. The result is a social construct of gender.

This should highlight the social nature of gender and emphasize that gender is under the constant influence of cultural norms that regulate the activity of men and women. It is also meant to acquaint people with the difference between men and women, as well as to reflect their socially constructed roles and responsibilities. That is to say that in the process of life there is a whole system that serves as a material for the construction of gender in a culture associated with maleness and femininity.

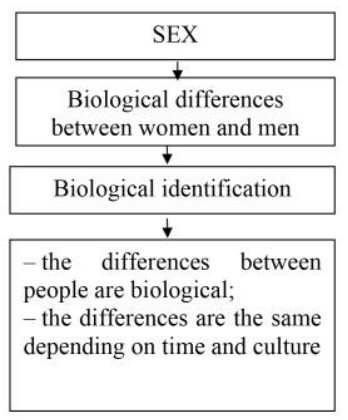

\begin{tabular}{l}
\hline \multicolumn{1}{|c|}{ GENDER } \\
\hline $\begin{array}{l}\text { Social-role status, which defines the social } \\
\text { possibilities of the person }\end{array}$ \\
\hline \multicolumn{1}{|c|}{ Social identification } \\
\hline $\begin{array}{l}\text { - the relationships between men and } \\
\text { relations; } \\
\text {-the differences vary depending on time } \\
\text { and culture }\end{array}$ \\
\hline
\end{tabular}

Fig. 1. Characteristics of the concepts of "sex" and "gender"

Thus, in its widest sense, "gender" is modeled by society and supported by social institutions, as wel as the socio-cultural system of values, norms and characteristics of male and female behavior received in the process of socialization.

In analyzing gender issues and identifying the notion of gender with the socio-cultural system of values, norms and characteristics, it should be emphasized that such a system is not absorbed in the process of socialization, but rather in the process of gender socialization. This inspired the second direction of our research: the disclosure of the entity "gender socialization» and its correlation with related concepts.

First of all, we have found that a number of studies done by teachers and psychologists present the results of exploring certain aspects of gender socialization. The analysis of the above-mentioned works confirms that at present there is no unified theory of gender socialization, there are only a few concepts, each of which has both strengths and weaknesses.

A variety of approaches to gender socialization causes the ambiguous interpretation of this notion, surveying it with definitions of differential, gender, rolegender, sex-role socialization. In considering a research 
objective, we analyzed the relevant concepts and we found that the most extensive one can be considered the concept of "differential socialization". "Differential socialization" is a phenomenon humancultural, i. e. girls and boys are socialized differently in all cultures. In most families the differential socialization begins even before birth, as future parents will want to know who is born: a boy or a girl. In addition, they do not like the misqualification of their child's gender.

Another approach is being formed within the framework of the theory of social construction of gender. We have defined it as a base in our study. The modelling of gender through everyday social practices resulting from the individual constructs of the idea of a male and a female identity, masculine and feminine behaviour, is what is important here. In this sense, the use of the notions of «role-gender» and «gender» socialization is just not quite correct and justified in the scientific circulation, in particular, to identify socio-cultural constructs. As we have already found above, the concept of "sex" reflects mainly the biological and physiological differences that you can understand, but do not acquire them after birth (according to role-gender theory). At the same time, in the theory of social gender construction, all components of the socialization of people of a certain gender are logically organized as a social and cultural phenomenon that causes the expediency of the use of the term "gender socialization."

\section{Results and discussion}

Taking into account the above-mentioned feature in the process of our analysis, we were able to separate three approaches to the concept of "gender socialization":

1) the object-object approach, according to which gender socialization is revealed as «a function of society, which is guiding the distribution of gender roles, the expansion of their range, the harmonization of interactions between sexes in accordance with cultural ideas about the role, the position and the appointment of sexes in society ... " (our italics. -V.S.);

2) the object-subject approach, that is, gender socialization that, on the one hand, "takes the leading place among the processes that develop, educate, form sexual consciousness of personality, and notes that thanks to it, the personality actively adopts standards of psychosocial culture", and on the other hand, "the personality, as subject, plays more actively the role of exposure to sexspecific behavior of other people offering its opinions, etc. " (our italics. -V.S.);

3) the subject-subject approach (individual in society). It involves the consideration of two interrelated parts of gender socialization: the personality that actively accepts models of male and female behaviour, attitudes, norms, values and stereotypes; and the influence of the social environment, defined by the community, rules and standards of conduct for men and women, on the personality with the purpose of instilling it in him/her. In addition, the analysis of the definitions of gender socialization, presented within the framework of the definite approach, has allowed us to highlight the following common signs of this phenomenon:
1) «process»;

2) «assimilation, interiorization, inheritance, adoption and reproduction $»$;

3) «sex roles and stereotypes», " social role», «socio-cultural values», «cultural and regulatory standards », «socio-cultural norms of behavior», «the cultural system of society»; der roles.

4) that society deems appropriate to their gen-

Since the subject-subject approach involves consideration of the society and the personality as two equal active principles, in our research we use the subject- subject approach. This approach predicts the consideration of gender socialization as a process of the influence of the social environment, defined by Community, rules and standards of men and women conduct, on the individual with the aim to instill it in him/her. Additionally, it is important for the individual to learn and reproduce actively the accepted models of male and female behavior.

Based on this understanding, the main functions of gender socialization of personality can be considered: attribution is the process of assimilation of the social experience, i. e., the impact of the environment on the individual and reproduction is the process of recreating the social experience, i. e., the impact of humans on the environment. In the framework of gender socialization, "attribution" means an idea (gender scheme), the time or period when the child discovers what it means to be a boy and a girl, a man and a woman; the process of reproduction correlates with the implementation in practice, learning the gender schemes. While the gender scheme can be understood as the cognitive network of associations, linked to gender behavior, it is reflected in the human consciousness.

As we have already mentioned above, the process of assimilation of gender representations, stereotypes of behavior and experience of relationships with the opposite sex, is multidimensional. That is why the objective of the third direction of our research was the discovery of the relationship between the "gender socialization", "gender training" and "gender education" categories.

In the process of theoretical analysis, it was found that the important parts or components of gender socialization (along with the gender self-development of personality) are gender training and gender education. First, it involves not only spontaneous and purposeful socialized effects, but also the self-realization of the personality, i.e. there is a two-way process. Secondly, it is realized through the function of assignment (gender training) and reproduction (gender education). It is especially appropriate to talk about the impact of gender training and gender education in the family, since it is the leading Institute of gender socialization.

In our opinion, the definition of gender training is quite correct and interesting, as proposed by Ivanova. She notes that it is "the process and the outcome of the assimilation of knowledge, abilities and skills for the purposes, standards and ways of constructing the social and cultural roles, behaviours, activities of the person, that are proposed by society. All this takes into account the biological sex that is aimed at understanding the es- 
sence of "male" and "female" as the social phenomenas" [8-10].

Main signs of gender education: it represents the purposeful, organized and managed educational activities that are aimed at fostering gender knowledge as a basis of gender consciousness. There is also the positive attitude towards the norms that regulate gender interaction, and towards the interactions and adequate gender behaviour with the aim to ensure equal rights and opportunities of men and women in various spheres of public life in society.

\section{Conclusion}

Therefore, the concept of "gender socialization" is in close connection with the concepts of "gender education" and "gender training" since the last ones implement its functions.

These phenomena are especially significant within the framework of our study because properly organized gender education and gender training determine the success of the process of gender socialization in general. And they form the basic knowledge about the gender characteristics of the personality which personality will play in the process of life.

Summarising the above defined positions, we proposed to describe the process of gender socialization of personality using the following equation:

\section{$\mathrm{GS}=\mathrm{GCh} \times(\mathrm{GT}+\mathrm{GE}+\mathrm{GSD})$,}

where gender;

- GCh is the gender characteristics, i. e. biological

- GT - gender training;

- GE - gender education;

- GSD - gender social development, that occurs through spontaneous absorption of gender perceptions, stereotypes, values and experience of gender-role behavior.

In analyzing the process and result of gender socialization of the personality, we emphasize, that it occurs in the course of interaction with others. The gender culture of a certain society consists of models of gender behaviors that arise in the communicative interaction between two different sexes and they constantly strengthen under the terms of the social environment.

In this connection, every cultural standard has its historical roots the connection with which is already lost, but it exists in the society as the gender stereotypes that are transferred from generation to generation.

Thus, the social consciousness supplies information in the form of stereotypes of regulatory behavior. The transition of these stereotypes, including the gender ones, comes from the information field of the public con sciousness to the personal thinking level of a particular person who will use them in his / her life. It happens in the process of gender socialization through targeted and spontaneous influence.

\section{References}

1. Social work / Social pedagogika: concept-terminology dictionary [Text] / I. D. Zvereva (Ed.). - Kyiv: Etnosfera, 1994. -119 p.

2. Lukashevich, M. P. Socialization. Educational mechanisms and technologies [Text]: educational-manual guide / M. P. Lukashevich. - Kyiv: IZMS, 1998. - 112 p.

3. Gender Pedagogy - a new educational technology [Electronic resource]. - Available at: http://osvita.ua/school/ method/upbring/1657/

4. Mudrik, A. V. Human socialization: manual for students [Text] / A. V. Mudrik. - Moscow: Academy, 2006. - 304 p.

5. Gender education - an urgent need for a modern educational system [Electronic resource]. - Available at: http:// ru.osvita.ua/school/method/upbring/330/

6. Gender socialization [Electronic resource]. - Available at: http://osvita.ua/school/method/upbring/1660/

7. Lauretis, T. D. Technologies of Gender: theories of representation and difference [Text] / T. D. Lauretis. - Bloomington: IndianaUniversity Press, 1987. $-76 \mathrm{p}$.

8. Ivanova, I. V. Preparing future teachers to gender training among senior pupils in the process of teaching and professional activities [Text]: abstract of thesis, the degree of PhD. / I. V. Ivanova. - Odessa, 2007. - 21 p.

9. Mudrik, A. V. Human socialization [Text]: manual for students / A. V. Mudrik. - Moscow: Academy, 2006. - 304 p.

10. American Sociological thought [Text] / V. I. Dobrenkova (Ed.). - Moscow: MSU, 1994. - 496 p.

References

1. Zvereva, I. D. (Ed.) (1994). Social work / Social pedagogika: concept-terminology dictionary. Kyiv: Etnosfera, 119.

2. Lukashevich, M. P. (1998). Socialization. Educational mechanisms and technologies. Kyiv: IZMS, 112.

3. Gender Pedagogy - a new educational technology. Available at: http://osvita.ua/school/method/upbring/1657/

4. Mudrik, A. V. (2006). Human socialization: manual for students. Moscow: Academy, 304.

5. Gender education - an urgent need for a modern educational system. Available at: http://ru.osvita.ua/school/ method/upbring/330/

6. Gender socialization. Available at: http://osvita.ua/ school/method/upbring/1660/

7. Lauretis, T. D. (1987). Technologies of Gender: theories of representation and difference. Bloomington: IndianaUniversity Press, 76.

8. Ivanova, I. V. (2007). Preparing future teachers to gender training among senior pupils in the process of teaching and professional activities. Odessa, 21.

9. Mudrik, A. V. (2006). Human socialization: manual for students. Moscow: Academy, 304.

10. Dobrenkova, V. I. (Ed.) (1994). American Sociological thought. Moscow: MSU, 496.

Syniakova Vira, PhD, Associate Professor, Department of theory and technology of social work, National Pedagogical Dragomanov University, Pirogova str., 9, Kyiv, Ukraine, 01601

E-mail: vsinyakova@ukr.net 